NiCHOLAS L. GEORGAKOPOULOS*

\title{
Visualizing Trials with Large DNA Databases
}

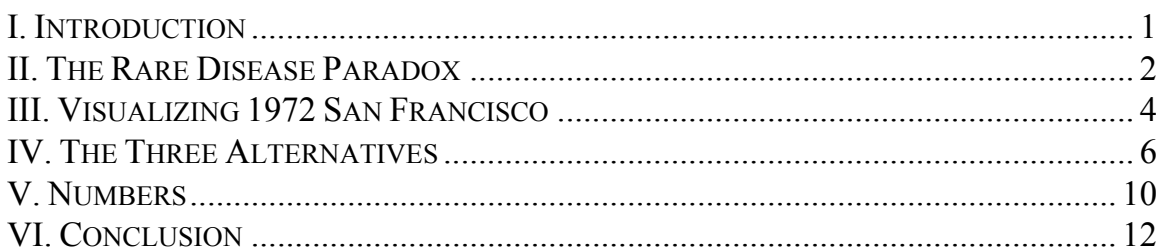

Abstract: This essay seeks to help the reader understand the use of probability theory in assessing DNA evidence drawn from large databases. I first guide the reader through visualizing a slightly simpler paradox of probability theory, the rare disease test. I then offer a visual understanding of the Puckett setting: DNA evidence from a large database identifies an individual but a deceased prime suspect exists whose DNA is not available. Effectively, the court needs to ascertain the probability that the third of three possible worlds has materialized. In the first possible world, the prime suspect, Baker, is the perpetrator and the court observes a false positive. The second possible world has an unknown perpetrator and again the court observes a false positive. The third world has Puckett as the perpetrator and the court observes a true positive. It turns out that the resulting posterior probabilities are strongly but not overwhelmingly in favor of the third possibility, true guilt.

\section{INTRODUCTION}

Probability theory, like the calculus, are relatively recent innovations that can be frustratingly counterintuitive. This is

*. Harold R. Woodard Professor of Law, Indiana University Robert H. McKinney School of Law, Indianapolis. I wish to thank ... I urge you to send your comments to me at ngeorgak@iu.edu. 